\title{
Productivity and Economics of Machine Transplanted Rice (Oryza sativa L.) as Influenced by Puddling Methods and Spacing
}

\author{
R. B. Negalur ${ }^{*}$, A. S. Halepyati ${ }^{2}$ and A. S. Channabasavanna ${ }^{3}$ \\ ${ }^{1}$ AICRP on Weed Management, Main Agricultural Research Station, ${ }^{2}$ Division of Agronomy, \\ ${ }^{3}$ Dept. of Agronomy, Agricultural Research Station, Malnoor, University of Agricultural Sciences, Lingsugur Road, UAS, \\ Raichur, Karnataka (584 104), India
}

Article History

Manuscript No. AR1553

Received in $4^{\text {th }}$ March, 2016

Received in revised form $14^{\text {th }}$ September, 2016

Accepted in final form $5^{\text {th }}$ October, 2016

\section{Correspondence to}

${ }^{*} E$-mail: tushberkipilli@rediffmail.com

\section{Keywords}

Puddling methods, spacing, machine transplanting, yield

\begin{abstract}
Field experiments were conducted on the effect of different puddling methods and various spacing on growth and yield of machine transplanted rice (Oryza sativa L.) at Agricultural Research Station, Gangavathi, University of Agricultural Sciences, Raichur, Karnataka during kharif, 2012 and 2013 in clay soil under irrigated condition. Pooled mean of two years indicated that among the different puddling methods and spacing. puddling with rotovator fb levelling with spike tooth harrow and spacing of $30 \times 21 \mathrm{~cm}^{2}$ recorded significantly higher dry matter accumulation in leaves $(13.44$ and $14.43 \mathrm{~g} \mathrm{plant}^{-1}$, respectively), stem (26.25 and $29.31 \mathrm{~g} \mathrm{plant}^{-1}$, respectively), panicles (37.21 and $41.38 \mathrm{~g} \mathrm{plant}^{-1}$, respectively), total dry matter accumulation in plant (73.82 and $85.12 \mathrm{~g} \mathrm{plant}^{-1}$, respectively) and leaf area plant ${ }^{-1}$ (1135 and 1229 $\mathrm{cm}^{2}$, respectively). Similarly, grain yield (4906 and $5192 \mathrm{~kg} \mathrm{ha}^{-1}$, respectively), straw yield (6247and $6508 \mathrm{~kg} \mathrm{ha}^{-1}$, respectively), gross returns ( $₹ 87,733$ and $92,779 \mathrm{ha}^{-1}$, respectively), net returns ( $₹ 46,329$ and 50,007 ha- ${ }^{-1}$ ) and benefit cost ratio (2.14 and 2.20) were also recorded with puddling with rotovator fb levelling with spike tooth harrow and $30 \times 21 \mathrm{~cm}^{2}$ spacing. Hence, on the basis of results obtained during both the years, combination of puddling with rotovator fb levelling with spike tooth harrow method of puddling and $30 \times 21 \mathrm{~cm}^{2}$ spacing was found better for transplanting of rice by self-propelled mechanical transplanter for Tungabhadra command area of Karnataka.
\end{abstract}

\section{Introduction}

Rice (Oryza sativa L.) is considered as the global grain. The World's most important crop and is a staple food for more than half of the World's population. Rice provides $30-75 \%$ of the total calories to more than 3 billion Asians (Khush, 2004). In India rice is grown on 42.50 mha with a production of 100.12 million tones with a productivity of $2400 \mathrm{~kg} \mathrm{ha}^{-1}$ (Anonymous, 2015). India is the second largest country of rice producer and rice continues to hold the key to sustain food production by contributing $20-25 \%$ of agriculture and assures food security in India for more than half of the total population (Anonymous, 2012).

Various tillage methods are being employed to prepare land for rice cultivation and effect of these tillage methods on hydraulic conductivity, infiltration rate, bulk density, cone index and rice yield are quite different. Use of most appropriate tillage implements in each region depends on availability of water, topography, climate, soil texture, type of rice culture, percolation, depth of water table, soil compaction, aggregation etc. (De Datta et al., 1988).

Texturally fine and moderately fine soils such as clayey and clay loam having clay as dominant component, high water holding capacity and less water intake rate are ideal for rice cultivation, which support power unit and implements while being operated for puddling in standing water. For rice, soil should be as compact and impermeable below the rooting depth as possible in order to impede the downward movement of water to the maximum. However, the root zone soil must be well pulverized and cultured for proper nourishment of plants (Razzaq, 1987). Now farmers are using conventional cultivator for preparing rice fields, which has less pulverizing action and least sealing effect at any level, as a result many repeats of cultivator followed by planking are required to 
transform the soil into the condition where rice nursery can be transplanted. This combination tends to compact the surface of soil instead of transforming impermeability below the root zone resulting in poor land manipulation at the cost of energy, time and machinery life and low yield of rice. The study of inter-relationship of soil, implement and crop is very much required. If farmers are shown the benefits of using appropriate implements, the objectives of mechanical cultivation can easily achieved (Razzaq, 1987).

Spacing is very important for optimum plant population per unit area and will be reflected on the yield of the crop. It is, therefore, necessary to determine the optimum density of plant population per unit area for obtaining maximum yield. Optimum plant spacing ensures plants to grow properly both in their aerial and underground parts through different utilization of solar radiation and nutrients (Baloch et al., 2002).

It is high time for mechanizing the transplanting operation in rice cultivation with suitable mechanical rice seedlings transplanter. Manes et al. (2013) reported huge labour saving with mechanical transplanters as compared to conventional manual transplanting. For conventional manual transplanting, 200 man hours ha ${ }^{-1}$ were used, while with SST (Selfpropelled single wheel transplanter), SWT (self-propelled walk behind transplanter) and for SFT (self-propelled fourwheel transplanter) man hours ha-1 used were 39, 13 and 24, respectively. Roughly, there was $78-88 \%$ labour saving in transplanting with the mechanical transplanter as compared to conventional manual transplanting.

\section{Materials and Methods}

The field experiments were conducted at Agricultural Research Station, Gangavathi, University of Agricultural Sciences, Raichur, Karnataka, during kharif, 2012 and 2013 laid in strip-plot design. The soil of the experimental site was medium deep black clay with soil reaction (8.2), electrical conductivity (2.1) determined following the procedure given by Jackson (1973), available N (247.2 $\left.\mathrm{kg} \mathrm{ha}^{-1}\right)$ (Subbaiah and Asija, 1956), available $\mathrm{P}_{2} \mathrm{O}_{5}\left(50.2 \mathrm{~kg} \mathrm{ha}^{-1}\right)$ (Olsen et al., 1954) and available $\mathrm{K}_{2} \mathrm{O}\left(357.6 \mathrm{~kg} \mathrm{ha}^{-1}\right)$ (Jackson, 1973) at surface 0-20 cm soil depth.

Agricultural Research Station, Gangavathiis situated in the Northen Dry Zone of Karnataka between $15^{\circ} 15^{\prime} 40^{\prime \prime}$ North latitude and $76^{\circ} 31^{\prime} 40^{\prime \prime}$ East longitude at an altitude of 419 $\mathrm{m}$ amsl and represents irrigated transplanted rice belt of Tungabhadra command area. The experiment consisted three different puddling methods viz., $\mathrm{L}_{1}$ : passing of cultivator twice $\mathrm{fb}$ puddling with disc puddler fb levelling with spiketooth harrow-Farmers practice, $\mathrm{L}_{2}$ : puddling with rotovator $\mathrm{fb}$ levelling with spiketooth harrow and $\mathrm{L}_{3}$ : puddling with rotomixure $\mathrm{fb}$ levelling with spike tooth harrow and three spacings planted by transplanter viz., $\mathrm{S}_{1}: 30 \times 7 \mathrm{~cm}^{2}, \mathrm{~S}_{2}: 30 \times 14$ $\mathrm{cm}^{2}$ and $\mathrm{S}_{3}: 30 \times 21 \mathrm{~cm}^{2}$ along with manual transplanting with $20 \times 10 \mathrm{~cm}^{2}$ spacing $\left(\mathrm{S}_{4}\right)$. The land was prepared using tractor drawn cultivator twice, followed by puddling twice with disc puddler and finally levelled using tractor drawn spike tooth harrow in case of farmers practice. Second type of land preparation was puddling with rotovator followed by levelling using tractor drawn spike tooth harrow. The other one was puddling with rotomixure and levelling was done using spike tooth harrow and kept ready for planting and seedlings raised in the trays were planted in the main field. Six days after transplanting, butachlor $50 \mathrm{EC}$ at the rate of $2.51 \mathrm{ha}^{-1}$ was sand mixed and broadcasted uniformly over the field containing a thin film of water followed by two hand weedings at 20 and 40 days after transplanting. From the day of transplanting up to 10 days, a thin film of water was maintained and thereafter $5 \mathrm{~cm}$ standing water was maintained up to 10 days before harvesting. Water was drained during fertilizer application and spraying of chemicals. Recommended dose of fertilizers (150:75:75 and $20 \mathrm{~kg} \mathrm{~N}: \mathrm{P}_{2} \mathrm{O}_{5}: \mathrm{K}_{2} \mathrm{O}$ and $\mathrm{ZnSO}_{4} \mathrm{ha}^{-1}$ ) were applied as per the method and time. Urea, Di-ammonium phosphate (DAP) and Muriate of potash (MoP) were used to supply N, P and K respectively. The recommended packages of practices were fallowed. The dry matter partitioning at different plant parts at definite interval of crop growth stages was recorded. The cost includes expenditure on seeds, fertilizers, irrigation, plant protection chemicals, hiring charges of transplanter, fuel cost and labour charges prevailed in market during 2012 and 2013. The data recorded at different stages of crop was subjected to statistical analysis at $5 \%$ probability.

\section{Results and Discussion}

\subsection{Dry matter accumulation}

\subsubsection{Puddling methods}

Significant response to both methods of puddling and spacing was exhibited by rice. Pooled data of two years indicated that significantly higher dry matter accumulation $\left(\mathrm{g} \mathrm{plant}^{-1}\right)$ in leaves, stem, panicles, total dry matter accumulation in plant $(9.62,11.99,9.73$ and $10.61 \%$, respectively) and leaf area plant $^{-1}(8.10 \%)$. (Table 1 and 2 ) was recorded with puddling with rotovator fb levelling with spike tooth harrow method of puddling over passing of cultivator twice fb puddling with disc puddler fb levelling with spike tooth harrow, but was found to be on par with puddling by rotomixure fb levelling with spike tooth harrow. Higher dry matter production (DMP) and it's partitioning into various plant parts was attributed to the maximum translocation of photosynthates to the sink which is the prerequisite for getting higher yields in any crop. Dry matter production (DMP) is the sum of dry matter accumulation 


\begin{tabular}{|c|c|c|c|c|c|c|c|c|c|}
\hline \multirow[t]{2}{*}{ Treatments } & \multicolumn{3}{|c|}{ DMA in leaves (g plant $\left.{ }^{-1}\right)$} & \multicolumn{3}{|c|}{ DMA in stem $\left(\mathrm{g}_{\text {plant }}{ }^{-1}\right)$} & \multicolumn{3}{|c|}{ DMA in panicles $\left(\mathrm{g} \mathrm{plant}^{-1}\right)$} \\
\hline & 30 DAT & 60 DAT & At harvest & $30 \mathrm{DAT}$ & 60 DAT & At harvest & 2012 & 2013 & Pooled \\
\hline \multicolumn{10}{|c|}{ Main treatments (A) } \\
\hline $\mathrm{L}_{1}$ & 3.13 & 13.42 & 12.26 & 4.06 & 20.28 & 23.44 & 32.56 & 35.26 & 33.91 \\
\hline $\mathrm{L}_{2}$ & 3.51 & 14.60 & 13.44 & 4.36 & 22.46 & 26.25 & 35.98 & 38.43 & 37.21 \\
\hline $\mathrm{L}_{3}$ & 3.34 & 14.30 & 13.15 & 4.22 & 21.12 & 25.25 & 34.64 & 36.89 & 35.77 \\
\hline $\mathrm{SEm} \pm$ & 0.07 & 0.23 & 0.19 & 0.23 & 0.36 & 0.41 & 0.59 & 0.47 & 0.56 \\
\hline $\mathrm{CD}(p=0.05)$ & NS & 0.90 & 0.73 & NS & 1.40 & 1.61 & 2.3 & 1.84 & 2.22 \\
\hline \multicolumn{10}{|c|}{ Sub treatments $(\mathrm{N})$} \\
\hline $\mathrm{S}_{1}$ & 3.19 & 13.90 & 12.67 & 4.01 & 19.62 & 23.37 & 32.38 & 34.77 & 33.57 \\
\hline $\mathrm{S}_{2}$ & 3.59 & 14.53 & 14.05 & 4.42 & 22.25 & 26.44 & 35.86 & 38.52 & 37.19 \\
\hline $\mathrm{S}_{3}$ & 3.97 & 15.89 & 14.43 & 4.62 & 25.45 & 29.31 & 40.1 & 42.66 & 41.38 \\
\hline $\mathrm{S}_{4}$ & 2.57 & 12.10 & 10.64 & 3.78 & 17.84 & 20.79 & 29.23 & 31.50 & 30.37 \\
\hline $\mathrm{SEm} \pm$ & 0.14 & 0.36 & 0.36 & 0.18 & 0.94 & 0.81 & 0.96 & 1.06 & 0.93 \\
\hline $\mathrm{CD}(p=0.05)$ & 0.48 & 1.25 & 1.24 & NS & 3.25 & 2.79 & 3.34 & 3.67 & 3.21 \\
\hline \multicolumn{10}{|c|}{ Interaction $(\mathrm{A} \times \mathrm{N})$} \\
\hline $\mathrm{L}_{1} \mathrm{~S}_{1}$ & 3.02 & 13.37 & 12.42 & 3.92 & 18.65 & 21.15 & 30.93 & 33.20 & 32.07 \\
\hline $\mathrm{L}_{1} \mathrm{~S}_{2}$ & 3.30 & 14.25 & 12.89 & 4.12 & 20.83 & 24.91 & 33.60 & 35.67 & 34.63 \\
\hline $\mathrm{L}_{1} \mathrm{~S}_{3}$ & 3.23 & 14.09 & 12.72 & 4.00 & 19.38 & 24.04 & 32.60 & 35.43 & 34.02 \\
\hline $\mathrm{L}_{1} \mathrm{~S}_{4}$ & 3.44 & 14.27 & 13.87 & 4.13 & 21.11 & 25.34 & 34.07 & 37.67 & 35.87 \\
\hline $\mathrm{L}_{2} \mathrm{~S}_{1}$ & 3.72 & 14.67 & 14.18 & 4.67 & 23.31 & 27.78 & 37.45 & 39.40 & 38.43 \\
\hline $\mathrm{L}_{2} \mathrm{~S}_{2}$ & 3.60 & 14.64 & 14.09 & 4.47 & 22.31 & 26.21 & 36.07 & 38.50 & 37.28 \\
\hline $\mathrm{L}_{2} \mathrm{~S}_{3}$ & 3.73 & 15.34 & 14.02 & 4.52 & 24.36 & 27.91 & 37.53 & 40.50 & 39.02 \\
\hline $\mathrm{L}_{2} \mathrm{~S}_{4}$ & 4.24 & 16.37 & 14.80 & 4.68 & 26.65 & 30.64 & 42.37 & 45.03 & 43.70 \\
\hline $\mathrm{L}_{3} \mathrm{~S}_{1}$ & 3.93 & 15.97 & 14.47 & 4.67 & 25.35 & 29.38 & 40.40 & 42.43 & 41.42 \\
\hline $\mathrm{L}_{3} \mathrm{~S}_{2}$ & 2.34 & 10.69 & 8.74 & 3.65 & 17.00 & 19.34 & 27.70 & 29.66 & 28.68 \\
\hline $\mathrm{L}_{3} \mathrm{~S}_{3}$ & 2.78 & 13.12 & 11.87 & 3.95 & 19.06 & 21.64 & 30.50 & 33.63 & 32.07 \\
\hline $\mathrm{L}_{3} \mathrm{~S}_{4}$ & 2.59 & 12.50 & 11.33 & 3.74 & 17.46 & 21.38 & 29.50 & 31.20 & 30.35 \\
\hline $\mathrm{SEm} \pm$ & 0.17 & 0.60 & 0.18 & 0.31 & 1.04 & 0.23 & 0.97 & 0.88 & 0.74 \\
\hline $\mathrm{CD}(p=0.05)$ & NS & NS & 0.57 & NS & NS & 0.70 & NS & NS & NS \\
\hline
\end{tabular}

NS: Non-significant; $\mathrm{L}_{1}$ : Cultivator (twice) fb pudling with disc puddler fb spike tooth harrow (PF); $\mathrm{L}_{2}:$ Puddling with rotovator $\mathrm{fb}$ spike tooth harrow; $\mathrm{L}_{3}$ : Puddling with rotomixture fb spike tooth harrow; $\mathrm{S}_{1}: 30 \times 7 \mathrm{~cm}^{2} ; \mathrm{S}_{2}: 30 \times 14 \mathrm{~cm}^{2} ; \mathrm{S}_{3}: 30 \times 21 \mathrm{~cm}^{2}$; $\mathrm{S}_{4}: 20 \times 10 \mathrm{~cm}^{2}$

in individual plant parts, which depends on the moisture, nutrients, method of puddling and availability of light. The higher dry matter production in case of puddling with rotovator $\mathrm{fb}$ levelling with spike tooth harrow method of land preparation perhaps may be attributed to enhanced growth parameters at all the growth stages of crop as a result of better utilization of nutrients as compared to other methods of puddlings. These findings are in conformity with the studies of (Razzaq, 1987; Rahamati and Solakhe, 2001; Amrendra Kumar et al., 2016 ).

\subsubsection{Spacing}

Rice dry matter production and partitioning was significantly influenced by different spacings. Planting at a spacing of $30 \times 21$ $\mathrm{cm}^{2}$ recorded significantly higher dry matter accumulation ( $\mathrm{g}$ plant $^{-1}$ ) in leaves (35.62\%), stem (40.98\%), panicles (36.25\%), total dry matter accumulation in plant $(37.73 \%)$ and leaf area plant $^{-1}(30.88 \%)$ over manual planting at spacing of $20 \times 10$ $\mathrm{cm}^{2}$, however, it was followed by intra plant spacing of $30 \times 14$ $\mathrm{cm}^{2}$ (Table 1 and 2). The increased dry matter production in 
Table 2: Total dry matter accumulation, grain yield, straw yield and economics of machine transplanted rice at different growth stages as influenced by Puddling methods and spacing (Pooled data of two years)

\begin{tabular}{|c|c|c|c|c|c|c|c|c|c|}
\hline \multirow[t]{2}{*}{ Treatments } & \multicolumn{3}{|c|}{ Total DMA $\left(\right.$ g plant $\left.^{-1}\right)$} & \multirow{2}{*}{$\begin{array}{l}\text { LA at } 60 \\
\text { DAT plant }{ }^{-1} \\
\quad\left(\mathrm{~cm}^{2}\right)\end{array}$} & \multirow{2}{*}{$\begin{array}{c}\text { Grain yield } \\
\left(\mathrm{kg} \mathrm{ha}^{-1}\right)\end{array}$} & \multirow{2}{*}{$\begin{array}{c}\text { Straw } \\
\text { yield } \\
\left(\mathrm{kg} \mathrm{ha}^{-1}\right)\end{array}$} & \multirow{2}{*}{$\begin{array}{l}\text { Gross } \\
\text { returns } \\
\left(₹ h^{-1}\right)\end{array}$} & \multirow{2}{*}{$\begin{array}{l}\text { Net } \\
\text { returns } \\
\left(₹ h^{-1}\right)\end{array}$} & \multirow{2}{*}{$\begin{array}{l}\text { Benefit cost } \\
\text { ratio }\end{array}$} \\
\hline & $\begin{array}{c}30 \\
\text { DAT }\end{array}$ & $\begin{array}{c}60 \\
\text { DAT }\end{array}$ & $\begin{array}{c}\text { At } \\
\text { harvest }\end{array}$ & & & & & & \\
\hline \multicolumn{10}{|c|}{ Main treatments (A) } \\
\hline $\mathrm{L}_{1}$ & 7.18 & 33.75 & 69.39 & 1050 & 4525 & 5648 & 80832 & 36212 & 1.83 \\
\hline $\mathrm{L}_{2}$ & 7.87 & 37.21 & 76.75 & 1135 & 4906 & 6247 & 87733 & 46329 & 2.14 \\
\hline $\mathrm{L}_{3}$ & 7.56 & 35.49 & 73.82 & 1105 & 4800 & 5870 & 85666 & 44104 & 2.09 \\
\hline $\operatorname{SEm} \pm$ & 0.38 & 0.44 & 0.89 & 12 & 50 & 104 & 905 & 1229 & 0.03 \\
\hline $\mathrm{CD}(p=0.05)$ & NS & 1.72 & 3.50 & 46 & 196 & 409 & 3552 & 4826 & 0.10 \\
\hline \multicolumn{10}{|c|}{ Sub-treatments $(\mathrm{N})$} \\
\hline $\mathrm{S}_{1}$ & 7.19 & 33.52 & 69.50 & 1075 & 4589 & 5747 & 81984 & 39539 & 1.95 \\
\hline $\mathrm{S}_{2}$ & 8.01 & 37.15 & 76.86 & 1142 & 4861 & 6152 & 86886 & 44294 & 2.07 \\
\hline $\mathrm{S}_{3}$ & 8.59 & 41.34 & 85.12 & 1229 & 5192 & 6508 & 92779 & 50007 & 2.20 \\
\hline $\mathrm{S}_{4}$ & 6.34 & 29.94 & 61.80 & 939 & 4334 & 5280 & 77325 & 35019 & 1.86 \\
\hline $\mathrm{SEm} \pm$ & 0.48 & 1.17 & 2.17 & 26 & 78 & 132 & 1304 & 1456 & 0.06 \\
\hline $\mathrm{CD}(p=0.05)$ & NS & 4.06 & 7.50 & 89 & 269 & 457 & 4503 & 5040 & 0.20 \\
\hline \multicolumn{10}{|c|}{ Interaction $(\mathrm{A} \times \mathrm{N})$} \\
\hline $\mathrm{L}_{1} \mathrm{~S}_{1}$ & 6.93 & 32.01 & 65.63 & 1042 & 4329 & 5738 & 77555 & 33033 & 1.76 \\
\hline $\mathrm{L}_{1} \mathrm{~S}_{2}$ & 7.42 & 35.08 & 72.43 & 1098 & 4766 & 5871 & 85083 & 43761 & 2.08 \\
\hline $\mathrm{L}_{1} \mathrm{~S}_{3}$ & 7.23 & 33.46 & 70.44 & 1086 & 4672 & 5632 & 83317 & 41825 & 2.03 \\
\hline $\mathrm{L}_{1} \mathrm{~S}_{4}$ & 7.57 & 35.61 & 74.23 & 1119 & 4792 & 6040 & 85642 & 40878 & 1.93 \\
\hline $\mathrm{L}_{2} \mathrm{~S}_{1}$ & 8.38 & 38.58 & 79.85 & 1165 & 4923 & 6326 & 88071 & 46659 & 2.15 \\
\hline $\mathrm{L}_{2} \mathrm{~S}_{2}$ & 8.07 & 37.25 & 76.43 & 1143 & 4867 & 6089 & 86946 & 45346 & 2.12 \\
\hline $\mathrm{L}_{2} \mathrm{~S}_{3}$ & 8.25 & 39.69 & 80.94 & 1185 & 5388 & 6789 & 96316 & 54649 & 2.33 \\
\hline $\mathrm{L}_{2} \mathrm{~S}_{4}$ & 8.92 & 43.01 & 89.14 & 1276 & 5118 & 6441 & 91460 & 46521 & 2.06 \\
\hline $\mathrm{L}_{3} \mathrm{~S}_{1}$ & 8.60 & 41.31 & 85.26 & 1227 & 5071 & 6293 & 90563 & 48854 & 2.20 \\
\hline $\mathrm{L}_{3} \mathrm{~S}_{2}$ & 5.98 & 27.68 & 56.76 & 853 & 3862 & 4375 & 68673 & 24417 & 1.57 \\
\hline $\mathrm{L}_{3} \mathrm{~S}_{3}$ & 6.73 & 32.18 & 65.58 & 1002 & 4548 & 6001 & 81463 & 40249 & 2.00 \\
\hline $\mathrm{L}_{3} \mathrm{~S}_{4}$ & 6.32 & 29.96 & 63.06 & 962 & 4592 & 5465 & 81840 & 40393 & 2.00 \\
\hline $\operatorname{SEm} \pm$ & 0.94 & 1.19 & 0.54 & 25 & 103 & 217 & 1620 & 1795 & 0.06 \\
\hline $\mathrm{CD}(p=0.05)$ & NS & NS & 1.66 & NS & 318 & 668 & 4992 & 5530 & NS \\
\hline
\end{tabular}

NS: Non-significant; $\mathrm{L}_{1}$ : Cultivator (twice) fb pudling with disc puddler fb spike tooth harrow $(\mathrm{PF})$; $\mathrm{L}_{2}$ : Puddling with rotovator fb spike tooth harrow, $\mathrm{L}_{3}$ : Puddling with rotomixture fb spike tooth harrow; $\mathrm{S}_{1}: 30 \times 7 \mathrm{~cm}^{2} ; \mathrm{S}_{2}: 30 \times 14 \mathrm{~cm}^{2} ; \mathrm{S}_{3}$ : $30 \times 21 \mathrm{~cm}^{2} ; \mathrm{S}_{4}: 20 \times 10 \mathrm{~cm}^{2}$

case of $30 \times 21 \mathrm{~cm}^{2}$ spacing might be due to obvious reasons of optimum plant population, better leaf area and availability of nutrients, water and energy so also wider feeding area offered by planting in wider row spacing resulting in opportunity for greater root growth, increased availability and accessibility of nutrients as reported by (Duraisamy et al., 2011, Sannagoudra et al., 2012; Barik et al., 2016).

\subsection{Yield}

\subsubsection{Puddling methods}

Methods of puddlings had significant influence on yield of rice. Significantly higher grain yield (4906 kg ha-1) and straw yield $\left(6247 \mathrm{~kg} \mathrm{ha}^{-1}\right)$ were recorded in the pooled mean data of two years with puddling by rotovator fb levelling with spike tooth harrow method of land preparation indicating 8.42 and $10.61 \%$ more yield over passing of cultivator twice fb puddling with disc puddler fb levelling with spike tooth harrow. However it 
was found to be on par with puddling by rotomixure fb levelling with spike tooth harrow method of puddling. The higher yield of rice in case of puddling with rotovator fb levelling with spike tooth harrow was mainly due to the fact that puddling with rotovator reduced bulk density and cone index in the plough layer compared to other puddling methods. Rahamati and Solakhe 2001; Tripathi et al., 2004, reported similar findings.

\subsubsection{Spacing}

Two year pooled mean data of grain yield $\left(5192 \mathrm{~kg} \mathrm{ha}^{-1}\right)$ and straw $\left(6508 \mathrm{~kg} \mathrm{ha}^{-1}\right)$ were noticed significantly higher with planting at a spacing of $30 \times 21 \mathrm{~cm}^{2}$ and were 19.80 and $23.26 \%$ higher grain and straw yield, respectively as compared to manual planting at a distance of $20 \times 10 \mathrm{~cm}^{2}$. However, it was found on par with spacing of $30 \times 14 \mathrm{~cm}^{2}$. These results are in agreement with the findings of (Krishna and Biradar, 2009; Duraisamy et al., 2011; Rasool et al., 2013) who reported increased rice grain yield with wider spacing as a result of more resources availability to the plants, more tillers with more growth above the ground for effective photosynthesis.

Grain and straw yield of machine transplanted rice was influenced significantly due to interaction of different Puddling methods and various spacing between the plants. Puddling with rotovator fb levelling with spike tooth harrow and intra plant spacing of $30 \times 21 \mathrm{~cm}^{2}$ treatment combination recorded significantly higher grain and straw yield (5388 and $6789 \mathrm{~kg}$ $\mathrm{ha}^{-1}$, respectively) and it was found to be on par with puddling with rotovator fb levelling with spike tooth harrow with $20 \times 10$ $\mathrm{cm}^{2}$ manual planting (5118 and $6441 \mathrm{~kg} \mathrm{ha}^{-1}$, respectively) and puddling with rotomixure $\mathrm{fb}$ levelling with spike tooth harrow with $30 \times 7 \mathrm{~cm}^{2}$ plant spacing (5071 and $6293 \mathrm{~kg} \mathrm{ha}^{-1}$, respectively).

\subsection{Economics}

Puddling with rotovator fb levelling with spike tooth harrow method of puddling and planting at spacing of $30 \times 21 \mathrm{~cm}^{2}$ recorded additional gross returns ( $₹ 6,901$ and 15,459 $\mathrm{ha}^{-1}$, respectively), net returns (₹ 10,117 and $14,988 \mathrm{ha}^{-1}$, respectively) and benefit cost ratio (2.14 and 2.20) over passing of cultivator twice $\mathrm{fb}$ puddling with disc puddler fb levelling with spike tooth harrow and manual planting treatments, but were found to be on par with puddling by rotomixure $\mathrm{fb}$ levelling with spike tooth harrow and planting at a spacing of $30 \times 21 \mathrm{~cm}^{2}$.

The interaction effect of land preparation and spacing between on gross and net returns was found significant. Puddling with rotovator fb levelling with spike tooth harrow with planting at spacing of $30 \times 21 \mathrm{~cm}^{2}$ treatment combination recorded significantly higher gross and net returns (₹ 96,316 and ₹ 54,649 ha-1, respectively) over rest of the treatment combinations.

\section{Conclusion}

Puddling with rotovator fb levelling with spike tooth harrow method of puddling and spacing of $30 \times 21 \mathrm{~m}^{2}$ was found to be the best combination for planting of rice seedling with self-propelled machine transplanter at irrigated rice belt of Tungabhadra command area of Karnataka.

\section{References}

Anonymous, 2012. Ministry of Agriculture, Govt. of India. http:// www.indiastat.com

Anonymous, 2015. Agricultural Statistics at glance, Directorate of economics and statistics. Department of Agriculture and Co-operation, Ministry of Agriculture, Government of India, 34-37.

Baloch, A.W., Soomro, A.M., Javed, M.A., Ahmed, M., 2002. Optimum plant density for high yield in rice (Oriza sativa L.). Asian Journal of Plant Science 1(1), 25-27.

Barik, A.K., Karmakar, M., Ghorai, S.K., 2016. Studies on the effect of crop geometry and nutrient management on productivity and economics of baby corn and cowpea (fodder) intercropping system. International Journal of Bio-resource and Stress Management 7(2), 305-309.

De Datta, S.K., Samson, M.I., Buresh, R.J., Wang Kai-Rong., 1988. Nitrogen use efficiency and nitrogenbalances in broadcast seeded, flooded and transplanted rice. Soil Science Society of American Journal 52(3), 849-855

Duraisamy, V.M., Senthilkumar, T., Subbulakhsmi, S., 2011. Studies on standardization of spacing and transplanting depth for a self-propelled rice transplanter. Agricultural Mechanization in Asia, Africa and Latin America 42(1), 42-44.

Jackson, M.L., 1973. Soil Chemical Analysis. Prentice-Hall of India, Pvt. Ltd., New Delhi, 121-125.

Khush, G.S., 2004. Harnessing science and technology for sustainable rice-based production systems. In: Proceedings of FAO Rice Conference "Rice is life". International Rice Commission Newsletter 53, 17-23.

Krishna, A., Biradar, N.K., 2009. Influence of seedling age and spacing on seed yield and quality of short duration rice under system of rice intensification. Karnataka Journal of Agricultural Sciences 22(1), 53-55.

Kumar, A., Singh Pal, M., Ramuand, N., Semwal, M.P., 2016. Effect of tillage and nutrient management on growth, yield, harvest index and nutrient use efficiency of wheat (Triticum aestivum L.) in Indo-gangetic plains of India. International Journal of Bio-resource and Stress Management 7(4) Special, 562-566.

Manes, G.S., Dixit, A., Singh, A., Mahal, J.S., Mahajan, G., 2013. Feasibility of mechanical transplanter for paddy transplanting in Punjab, Agricultural Mechanization in 
Asia, Africa and Latin America 44(3), 14-17.

Olsen, S.R., Cole, C.L., Watanabe, F.S., Deaw, D.A., 1954. Estimation of available phosphorous in soils by extraction with sodium bicarbonate. United States Departments of Agriculture circular, 939.

Rahamati, M.H., Solakhe, V.M., 2001. Effect of tillage practices on hydraulic conductivity, cone index, bulk density, infiltration rate and rice yield during rainy season in Bangkok clay soil. Agricultural Mechanization in Asia, Africa and Latin America 32(3), 31-34.

Rasool, F., Habib, R., Bhat, M.I., 2013. Agronomic evaluation of rice (Oryza sativa $\mathrm{L}$.) for plant spacing and seedlings per hill under temperate conditions. Pakistan Journal of Agricultural Sciences 9, 169-172.
Razaaq, A., 1987. Preparation of Medium-Textured soil for Rice Production. Agricultural Mechanization in Asia, Africa and Latin America 18(1), 19-21.

Sannagoudra, H.M., Dasog, G.S., Patil, P.L., Hanamaratti, N.G., 2012. Yield and nitrogen uptake by drill sown paddy as affected by different coatings of urea under two row spacings. Karnataka Journal of Agriculture Sciences 25(4), 535-536.

Subbaiah, B.V., Asija, G.L., 1956. Rapid procedure for determination of available nitrogen in soils. Current. Science 31, 196.

Tripathi, S.K., Jena, H.K., Panda, P.K., 2004. Self-propelled rice transplanter for economizing labour. DARE/ICAR Annual Report, 23-25. 